\title{
Influence of Underground Excavation of Large-Section Intercity Railway Tunnel on Adjacent Pile Foundation
}

\author{
Junfu $\mathrm{Lu}^{1,2, *}$, Dongming $\mathrm{Li}^{1}$, Feng $\mathrm{Ji}^{1}$ and Wenlai $\mathrm{Xu}^{1}$ \\ ${ }^{1}$ State Key Laboratory of Geohazard Prevention and Geoenvironment Protection, Chengdu University of Technology, \\ Chengdu 610059, China; ${ }^{2}$ China Railway Eryuan Engineering Group Co. Ltd, Chengdu 610031, China
}

\begin{abstract}
Three-dimensional model is established with finite difference method to simulate construction process based on design and construction plans of existing overpass pile foundation adjacent to certain large-section railway tunnel in Chengdu, China. Ground, isolation pile, main bridge pier and ramp pile near the tunnel are taken as research object, and surface settlement amount, displacement change law of each pile foundation and structural mechanics property are analyzed to further judge whether safety of adjacent overpass structure can be ensured during construction in accordance with used tunnel design and construction plans. Research result shows that the maximum value of surface settlement amount is $13 \mathrm{~mm}$, and settlement range is within $8 \mathrm{~m}$ at two sides of tunnel axis; and the settlement amount of pile top of main bridge pier is greatest, referring to $47 \mathrm{~mm}$. Axial force and bending moment borne by the main bridge pier are greatest, and horizontal displacement and bending moment distribution at different positions of the main bridge pier at two sides of the tunnel have the characteristics of right-and-left symmetry, and point of inflection is at the position being $1 / 3$ of pile length away from the pile top, while point of inflection of isolation pile is at the position being $2 / 5$ of pile length away from the pile top, and reinforcement of the pile body may be adjusted accordingly. The pile with minimum safety factor is the isolation pile which is closest to the tunnel, and the minimum safety factor is 3.5. As displacement value of each pile foundation is within allowed range, and safety factor meets standard requirement, so construction as per the design and construction plan may ensure safety of adjacent overpass structure.
\end{abstract}

Keywords: Intercity railway tunnel, mechanical property, pile foundation, subsurface excavation.

\section{INTRODUCTION}

In recent years, the conditions of new tunnel adjacent to the construction pile foundation and the tunnel crossing the pile foundations with the intercity high-speed railway increasing. Surrounding rock stress redistributionis resulted from new tunnel construction and the existing pile foundation locating at the surrounding rock stress redistribution zone has bad effect on its structure safety leading to instability and damage of the pile foundation [1], and moreover, threatening the upper structure safety. Therefore, study on the influence of new tunnel construction on adjacent existing pile foundation has the important engineering meaning in actual project. Study on the influence of tunnel excavation on adjacent pile foundation started from the model test by Morton and othersin the 1970s [2], so far, domestic and foreign scholars have conducted a lot of studies on it.

Sun Weimin and others analyze the vertical displacement and local gradient of the pipelines and the ground settlement of one tunnel surrounding in Shenzhen using finite element method [3]. Yang Xiaojie and others study on the lateral friction resistance of pile [4], total pile-end resistance and axial force of the pile bottom end etc. using numerical simulation analysis based on finite difference method. Liu Feng and others analyze the reaction and change law of the single pile resulted from the tunnel excavation at the time of change of the horizontal distance between adjacent pile foundation and vertical axis of tunnel and change of the pile length using ABAQUS [5]. Yang Min and others discuss influences of tunnel excavation on the settlement, axial force, lateral deformation, bending moment and pile group effect of the adjacent pile foundation [6]. Shi Chenghua and others analyze the influence of tunnel excavation on the surface buildings using stochastic medium theory [7]. S. W. Jacobsz and othersanalyze the influence of cavern excavation on driven pile in formation condition of dense and dry sand soil [8]. N. Loganathan and others learn the influence of tunnel construction on the ground movement and adjacent pile foundation using centrifuge model test [9]. Takahashi and otherscontrol use grouting technique to reinforce tunnel surrounding soil and strict construction management to control the settlement of building for the working condition of doubletrack tunnel of Tokyo Waterfront New Transit trough a pile foundation [10]. Mair and others study on the influence of tunnel excavation on the ground settlement using analytical method based on Peck formula [11-13].

Based on the design and construction scheme of a new large section intercity railway tunnel crossing existing overpass pile foundation in Chengdu, using finite difference method, this paper constructed a three dimensional model to simulate the construction process, selected adjacent substances such as the ground, the isolation pile, the main pile 
and the ramp pile adjacent to the tunnel as research objects, analyzed ground settlement as well as displacement law and mechanical properties of existing overpass pile foundation in the process of new tunnel construction.

\section{MATERIALS AND METHODS}

\subsection{Research Object}

New tunnel crosses obliquely the overpass and the crossing angle is about $70^{\circ}$. Fig. (1) is the cross section perpendicular to the track alignment and the distance of each pile in the Figure is the projected length of actual distance on the section. Isolation pile, main pile and ramp pile is located in turn near the tunnel, burial depth of tunnel is $12 \mathrm{~m}$, the tunnel span is $15 \mathrm{~m}$, the existing pile foundation on its both side, the distance from the center of the main pile foundation to the right wall of the tunnel is $2.5 \mathrm{~m}$, the diameter of the main pile on both side is $1.8 \mathrm{~m}$ and pile length is $25 \mathrm{~m}$, the diameter of the farther main pile (the position at $6.5 \mathrm{~m}$ from the right wall of tunnel), located at gravel formation, is $1.5 \mathrm{~m}$ and the pile length is $15 \mathrm{~m}$; the distance from the center of the ramp pile foundation to the tunnel boundary is $7 \mathrm{~m}$, the diameter of its pile foundation is $1.5 \mathrm{~m}$ and pile length is 20 m.

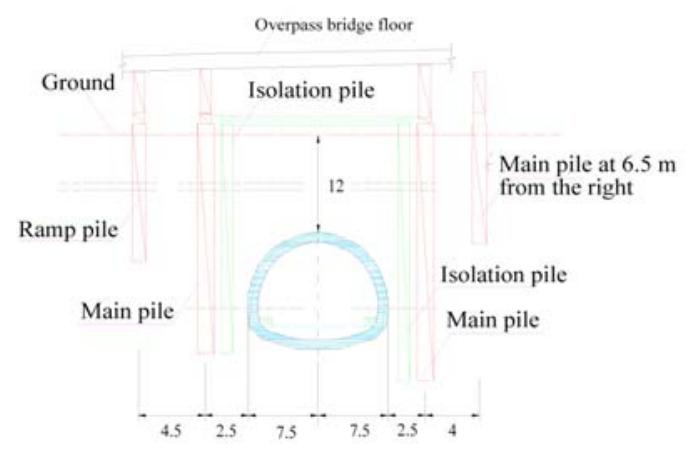

Fig. (1). Cross section of subsurface excavation tunnel crossing pile foundations of overpass (unit: $\mathrm{m}$ ).

\subsection{Construction of the Isolation Pile}

The isolation piles are constructed at both side of the tunnel of lower overpass section to protect the existing overpass pile foundation and reduce the influence on the pile foundation so as to ensure the safety of operation in this section. The isolation pile is $\mathrm{C} 30$ concrete bored pile with 1.2 $\mathrm{m}$ in diameter, $25 \mathrm{~m}$ in length and closed-spaced layout. Reinforced concrete support is for the isolation pile top and the support section size is $60 \mathrm{~cm} \times 80 \mathrm{~cm}$ (width $\times$ height).

\subsection{Parameters of the Support}

Use double - side - wall heading method for the construction of DK166+395 +435 section with C25 shotcrete, I25a section steel frame and $0.5 \mathrm{~m}$ in axial space. $\Phi 42$ doublelayer small pipe grouting and big pipe shed reinforcement is used at $140^{\circ}$ range of arch. Small pipe of the first layer: 3.5 $\mathrm{m}$ in length, $0.3 \mathrm{~m}$ in circumferential space, $0.1 \mathrm{~m}$ in axial space and $30 \sim 35^{\circ}$ of external ccomer key. Small pipe of the second layer: $2.5 \mathrm{~m}$ in length, $0.3 \mathrm{~m}$ in circumferential space, $0.1 \mathrm{~m}$ in axial space and $10 \sim 15^{\circ}$ of external ccomer key.
$\Phi 159$ double-layer big pipe shed is adopted at $1400^{\circ}$ of $\operatorname{arch}$ ( $8 \mathrm{~mm}$ in wall thickness) and big pipe shed is $0.3 \mathrm{~m}$ in circumferential space, $40 \mathrm{~m}$ in length and $1^{\circ}$ of external comer angle. $3 \Phi 18$ steels are inserted into the pipe with pressure injection of cement mortar. $\Phi 25$ fiber rock bolt, injected with cement grout, is constructed at upper semi-section tunnel face with $8 \mathrm{~m}$ in length, $0.8 \mathrm{~m}$ in horizontal space, quincunx layout, $6 \mathrm{~m}$ in axial space.

\subsection{Calculation Parameters}

Define the calculation parameters based on the engineering geology condition and the designed parameters of the support, as shown in Table $\mathbf{1 .}$

\subsection{Calculation Model}

(1) Conduct three-dimensional model calculation with finite difference method. Burial depth of tunnel is $12 \mathrm{~m}$, the tunnel span is $15 \mathrm{~m}$, the existing pile foundation are constructed respectively on its both side, the distance from the center of the main pile foundation to the tunnel boundary is $2.5 \mathrm{~m}$, the diameter of the main pile on both side is $\varphi 1.8 \mathrm{~m}$ and pile length is $25 \mathrm{~m}$, the diameter of the farther main pile, located at gravel formation, is $\varphi 1.5 \mathrm{~m}$ and the pile length is $15 \mathrm{~m}$; the distance from the center of the ramp pile foundation to the tunnel boundary is $7 \mathrm{~m}$, the diameter of its pile foundation is $\varphi 1.5 \mathrm{~m}$ and pile length is $20 \mathrm{~m}$. The load of the main pile top is $3000 \mathrm{kN}$ and that of the ramp pile top is 500 $\mathrm{kN}$.

(2) The soil range of the model calculation is as follows: $40 \mathrm{~m}$ in soil thickness ( $\mathrm{Y}$ direction), $7 \mathrm{~m}$ in axis ( $\mathrm{Z}$ direction) and $80 \mathrm{~m}$ in width (X direction). The model is divided into 26362 elements and 31128 points. Adopt solid element for the isolation pile, main pile, ramp pile and surrounding rock in this model.

(3) Boundary conditions of the model: the surface on all sides is limited horizontally, lower boundary is limited vertically and the upper boundary (ground) is free. The whole model with self-weight stress field $g=9.8 \mathrm{~m} / \mathrm{s} 2$.

\section{Calculation model meshing is shown in the Fig. (2).}

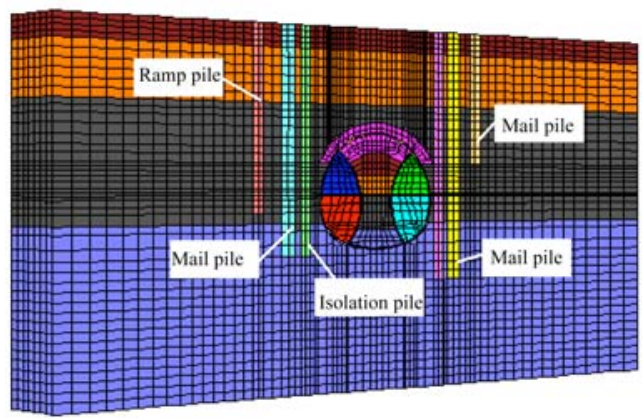

Fig. (2). 3D finite element model.

\subsection{Construction Process Model of Subsurface Excava- tion}

Schematic diagram of construction process of double side - wall heading method is shown in the Fig. (3). 
Table 1. Physical and mechanical parameters of surrounding rock and support.

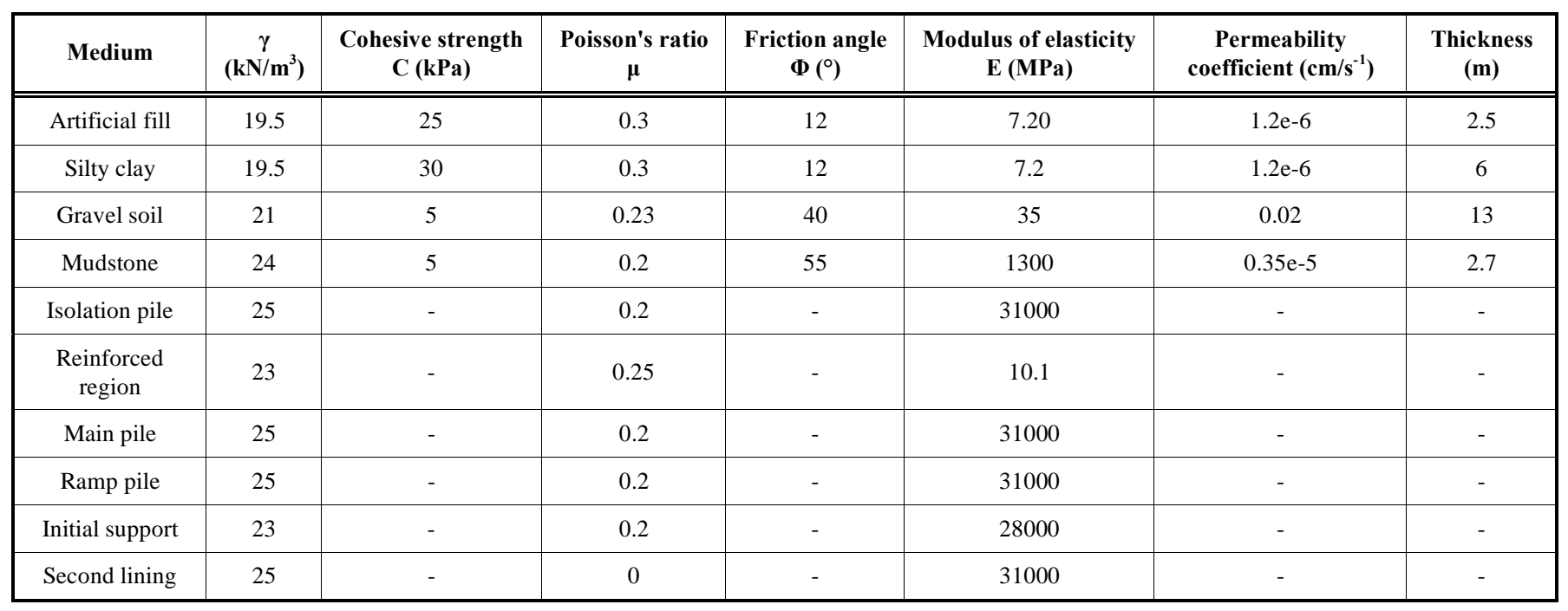

(1) The application of reinforced concrete isolation pile: the isolation pile with closed-spaced layout and $\varphi 1.2 \mathrm{~m}$ diameter and its bottom end is inserted into $3 \mathrm{~m}$ under the tunnel invert;

(2) Step 1: excavate the ground at 0-2 $\mathrm{m}$ of the upper part of the left heading;

(3) Step 2: excavate the ground at 2-5 $\mathrm{m}$ of the upper part of the left heading and the ground at 0-2 $\mathrm{m}$ of its lower part;

(4) Step 3: excavate the ground at 5-7 $\mathrm{m}$ of the upper part of the left heading, the ground at 2-5 m of its lower part and the ground at $0-2 \mathrm{~m}$ of the upper part of the right heading;

(5) Step 4: excavate the ground at 5-7 $\mathrm{m}$ of the upper part of the left heading, the ground at $2-5 \mathrm{~m}$ of the upper part of the right heading and the ground at $0-2 \mathrm{~m}$ of the lower part of the right heading;

(6) Step 5: 5-7 $\mathrm{m}$ of the upper part of the right heading, 2-5 $\mathrm{m}$ of its lower part and 0-2 $\mathrm{m}$ of upper bench at the upper part of the middle heading;

(7) Step 6: 5-7 $\mathrm{m}$ of the lower part of the right heading, 2-5 $\mathrm{m}$ of upper bench at the upper part of the middle heading and $0-2 \mathrm{~m}$ of middle bench at the upper part of the middle heading;

(8) Step 7: 5-7 $\mathrm{m}$ of upper bench at the upper part of the middle heading, 2-5 $\mathrm{m}$ of middle bench at the upper part of the middle heading and 0-2 $\mathrm{m}$ of lower bench at the upper part of the middle heading;

(9) Step 8: 5-7 $\mathrm{m}$ of middle bench at the upper part of the middle heading, 2-5 $\mathrm{m}$ of lower bench at the upper part of the middle heading and $0-2 \mathrm{~m}$ of upper bench at the lower part of the middle heading;

(10) Step 9: 5-7 $\mathrm{m}$ of lower bench at the upper part of the middle heading, 2-5 $\mathrm{m}$ of upper bench at the lower part of the middle heading and 0-2 $\mathrm{m}$ of lower bench at the lower part of the middle heading;

(11) Step 10: 5-7 $\mathrm{m}$ of upper bench at the lower part of the middle heading and 2-5 $\mathrm{m}$ of lower bench at the lower part of the middle heading;
(12) Step 11: 5-7 $\mathrm{m}$ of lower bench at the lower part of the middle heading;

(13) Step 12: remove the temporary support 0-2 m;

(14) Step 13: remove the temporary support 2-5 m;

(15) Step 14: remove the temporary support 5-7 m.

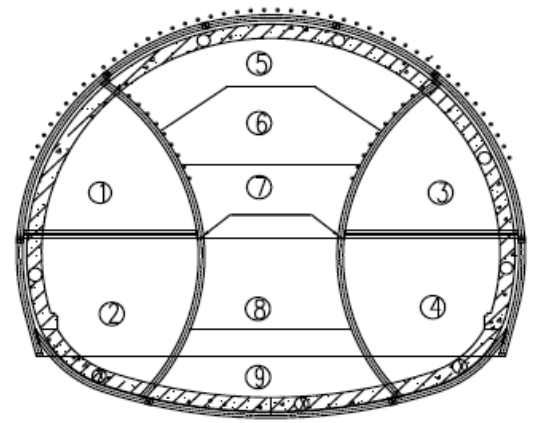

Fig. (3). Schematic diagram of construction process of double - side - wall heading method.

\section{ANALYSIS ON THE NUMERICAL CALCU- LATION RESULTS}

\subsection{Analysis on the Ground Displacement}

Analyze the vertical displacement of the ground with different distances from the tunnel axis according to the calculation results, as shown in Fig. (4).

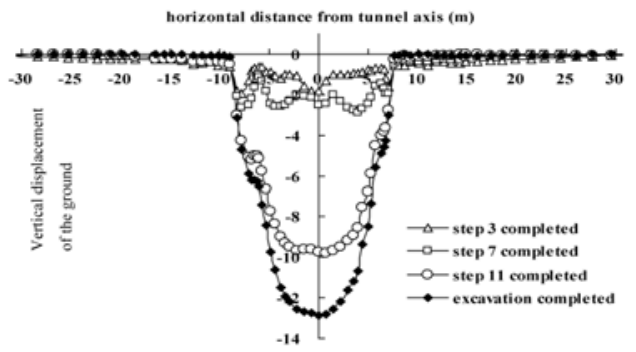

Fig. (4). Disposal chart of ground settlement during different construction processes. 


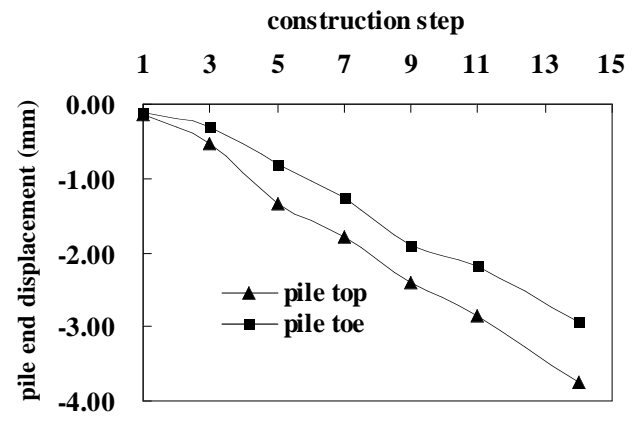

(a) Isolation pile on the left

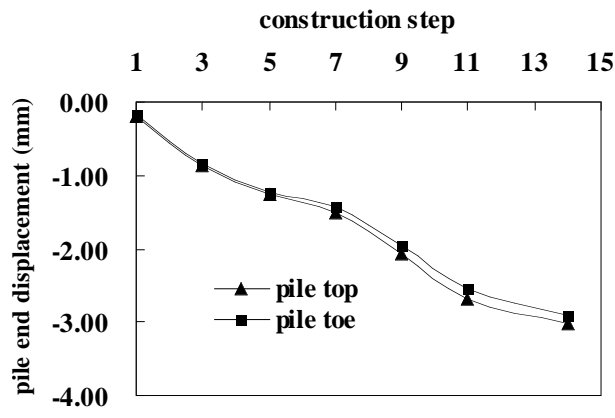

(c) Main pile on the left

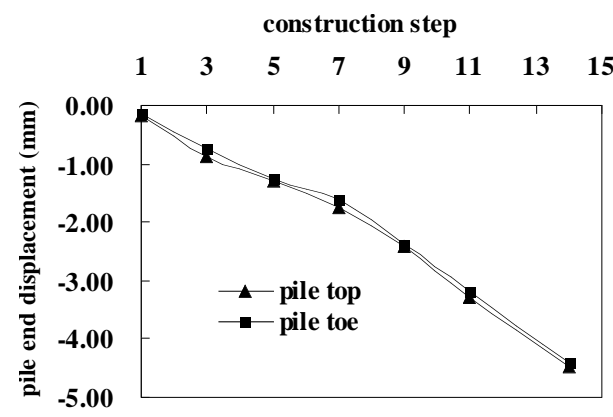

(e) Ramp pile on the left

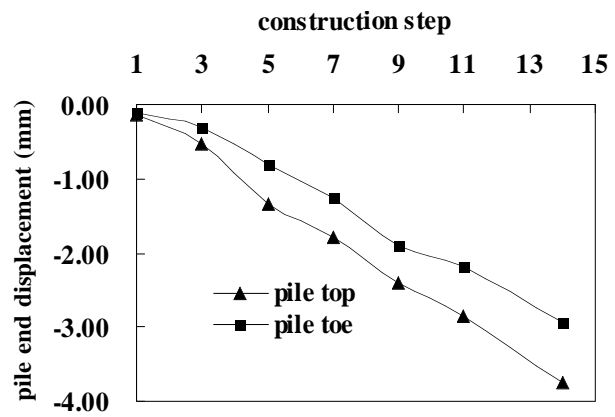

(b) Isolation pile on the right

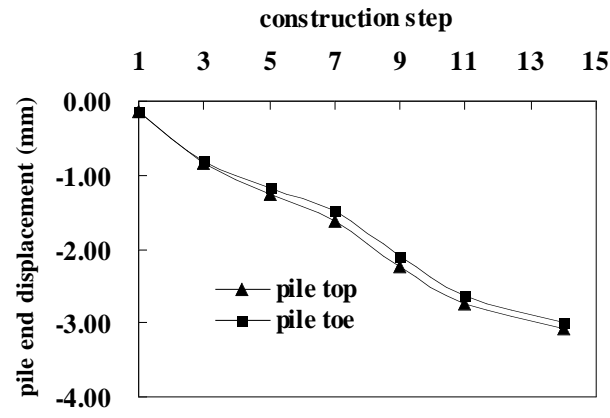

(d) Main pile on the right

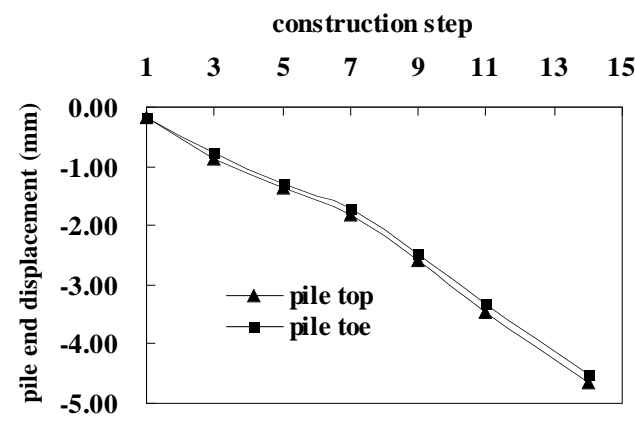

(f) Main pile at $6.5 \mathrm{~m}$ from the right

Fig. (5). Vertical displacement of piles.

In Fig. (4), we learn that the settlement range is within 8 $\mathrm{m}$ from tunnel axis directly over the tunnel excavation range and that the closer from tunnel axis, the larger for the settlement. The ground settlement increases with the excavation and maximum of ground settlement $13 \mathrm{~mm}$ occurs after the tunnel construction completed.

\subsection{Analysis on Vertical Displacement of Pile Foundation}

In Fig. (5), we learn that pile settlement increases with the excavation and that the other existing overpass pile foundations have no obvious vertical deformation except for slight vertical deformation of the isolation pile. The removal of transverse support has more influence on the vertical displacement of the isolation pile and the displacement resulted from the removal of temporary support accounts for $20 \%$ of the total displacement. Pile top settlements in turn: $3.2 \mathrm{~mm}$ for isolation pile on the left; $3.0 \mathrm{~mm}$ for isolation pile on the right; $2.9 \mathrm{~mm}$ for main pile on the left; $3.1 \mathrm{~mm}$ for main pile on the right; $4.4 \mathrm{~mm}$ for ramp pile on the left; $4.7 \mathrm{~mm}$ for main pile at $6.5 \mathrm{~m}$ from the right.

\subsection{Analysis on Horizontal Displacement of Pile Founda- tion}

Analyze the horizontal displacement of different parts of the isolation pile, overpass main pile and ramp pile at both side of the tunnel according to the calculation results, as shown in Fig. (6).

In Fig. (6) we can learn that the horizontal displacement value of each pipe foundation increases gradually with construction process and peaks after the tunnel excavation completed. Maximum horizontal displacement of each pile in turn: For isolation pile on the left, right displacement $1.7 \mathrm{~mm}$ of pipe top; For main pile on the left, right displacement 2.1 $\mathrm{mm}$ of the part at $5 \mathrm{~m}$ from pile top; For ramp pile on the left, right displacement $2.4 \mathrm{~mm}$ of the part at $7 \mathrm{~m}$ from pile top; For isolation pile on the right, right displacement 2.3 


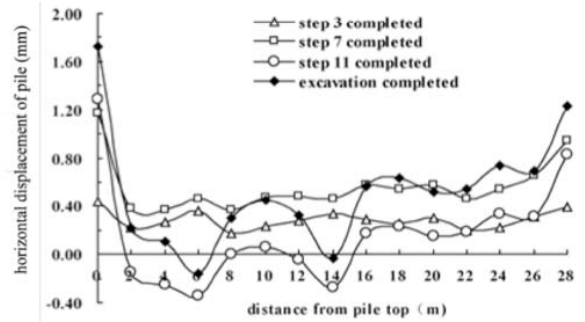

(a) Isolation pile on the left

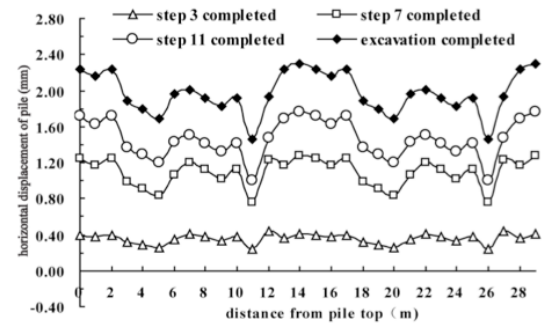

(d) Isolation pile on the right

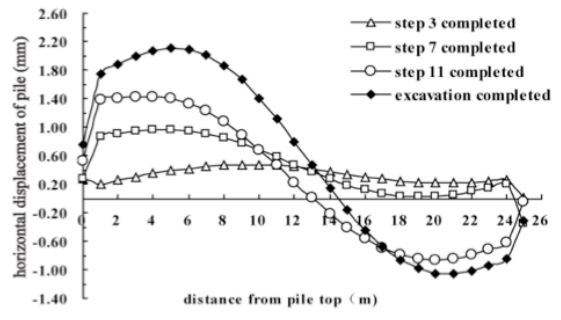

(b) Main pile on the left

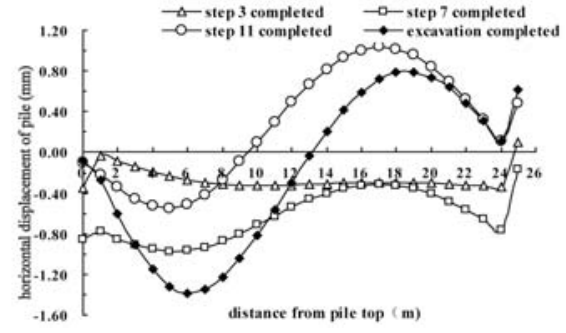

(e) Main pile on the right

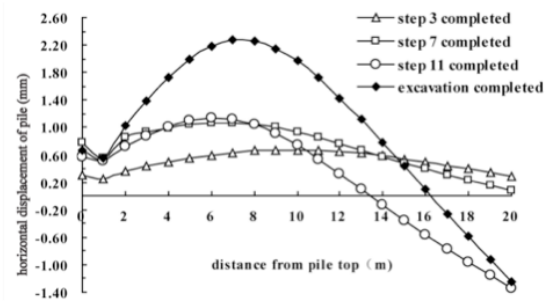

(c) Ramp pile on the left

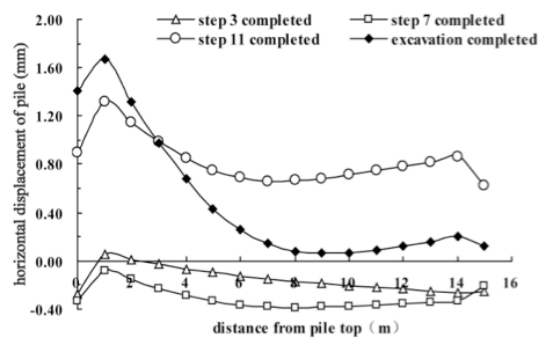

(f) Main pile at $6.5 \mathrm{~m}$ from the right of tunnel

Fig. (6). Horizontal displacement of piles.

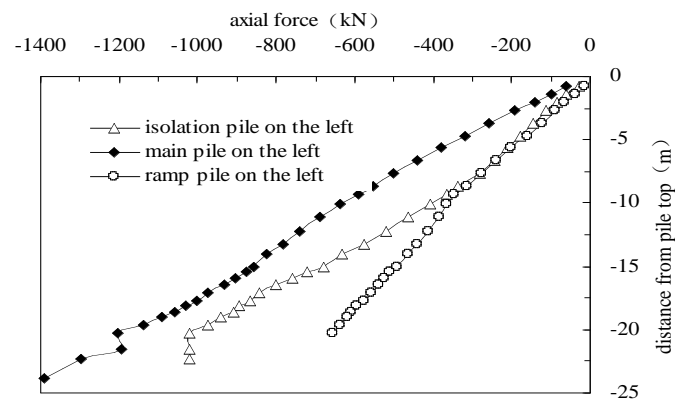

(a) Axial force distribution of each pile on the left

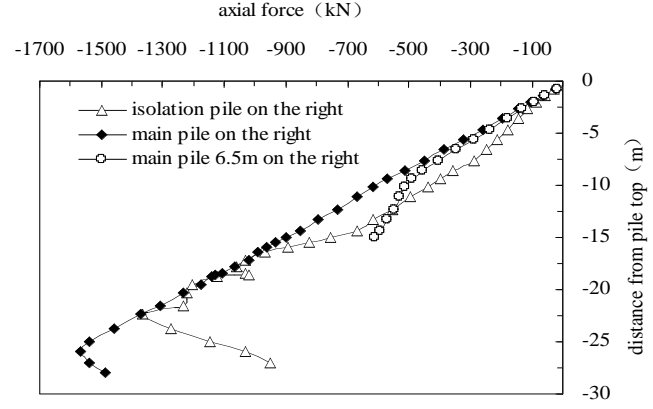

(b) Axial force distribution of each pile on the right

Fig. (7). Axial force of piles after excavation completed.

$\mathrm{mm}$ of middle part of the pile; For main pile on the right, left displacement $1.4 \mathrm{~mm}$ of the part at $6 \mathrm{~m}$ from pile top; For main pile at $6.5 \mathrm{~m}$ from the right, right displacement $1.8 \mathrm{~mm}$ of the part at $1 \mathrm{~m}$ from pile top.

The horizontal displacement of each part of the isolation pile on the right in (d) is the most uniform with the characteristic of overall moving horizontally towards right. After comparing the main pile on the left with that on the right, we learn that upper part of left pile moves towards right, lower part towards left and the pile body tends to inclining towards the tunnel and that upper part of right pile moves towards left, lower part towards right, the pile body tends to inclining towards the tunnel as well. Above all, the trend is related with surrounding rock stress redistribution after the tunnel excavation.

\subsection{Analysis on Axial Force of Pile Foundation}

Analyze the axial force distribution of the isolation pile, main pile and ramp pile at both side of the tunnel after the tunnel excavation completed according to the calculation results, as shown in Fig. (7).

Form Fig. (7), we learn that axial force distribution of each pile on the left increases gradually from top to bottom and peaks at the pile bottom while axial force distribution of isolation pile and main pile on the right increases, then decreases and peaks at the part about $3 \mathrm{~m}$ from the pile bottom. Maximum axial force of each pile in turn: For isolation pile on the left, the maximum axial force of the pile body is about $1022 \mathrm{kN}$ at pile bottom end; For main pile on the left, the maximum axial force of the pile body is about $1388.7 \mathrm{kN}$ at pile bottom end; For ramp pile on the left, the maximum axial force of the pile bottom is about $654 \mathrm{kN}$; For isolation pile on the right, the maximum axial force of the pile body is about $1368 \mathrm{kN}$ at the upper part of $5 \mathrm{~m}$ from pile bottom end; For main pile on the right, the maximum axial force of the pile body is about $1565.1 \mathrm{kN}$ at the upper part of $2 \mathrm{~m}$ from pile bottom end; For main pile at $6.5 \mathrm{~m}$ from the right, the maximum axial force of the pile body is about $609.3 \mathrm{kN}$ at pile bottom end.

\subsection{Analysis on The Bending Moment of Pile Foundation}

Analyze the bending moment distribution of the isolation pile, overpass main pile and ramp pile at both side of the tunnel after the tunnel excavation completed according to the calculation results, as shown in Fig. (8). 


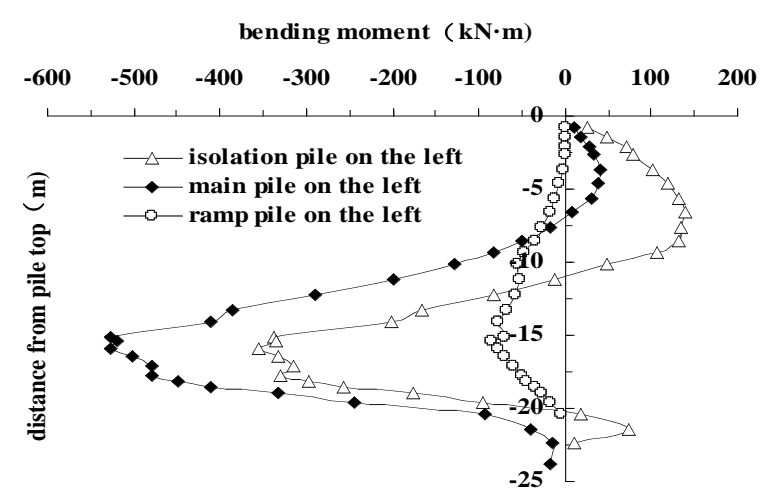

(a) Bending moment distribution of each pile foundation on the left

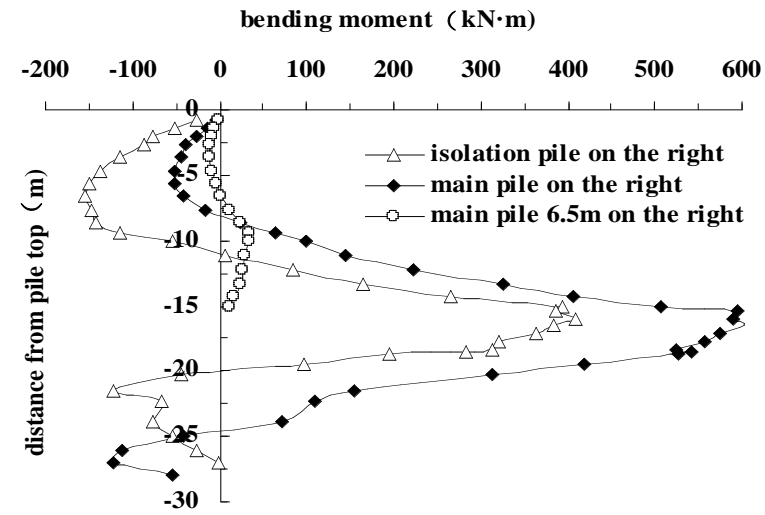

(b) Bending moment distribution of each pile foundation on the right

Fig. (8). Bending moment of piles after excavation completed.

In Fig. (8), we learn that the maximum bending moment value of each pile occurs at the part about $16 \mathrm{~m}$ from the pile top except for the excessively short main pile at $6.5 \mathrm{~m}$ from right and that bending moment value of the main pile on both side is more than that of other pile foundations and the bending moment of each pile on both side is distributed symmetrically. Maximum bending moment and inflection point location of each pile in turn: For isolation pile on the left, maximum negative bending moment is $-352.4 \mathrm{kN} . \mathrm{m}$, maximum positive bending moment is about $138.79 \mathrm{kN} . \mathrm{m}$ and the inflection point is $11 \mathrm{~m}$ from the pile top; For main pile on the left, maximum negative bending moment is about $-527 \mathrm{kN} . \mathrm{m}$, maximum positive bending moment is about 39 kN.m and

the inflection point is $7.5 \mathrm{~m}$ from the pile top; For ramp pile on the left, maximum bending moment is about -84.4 $\mathrm{kN}$.m and the bending moment of pile body is negative bending moment; For isolation pile on the right, maximum positive bending moment is $409.4 \mathrm{kN} . \mathrm{m}$, maximum negative bending moment is about $-155.8 \mathrm{kN} . \mathrm{m}$ and the inflection point is $10 \mathrm{~m}$ from the pile top; For main pile on the right, maximum positive bending moment is about $603 \mathrm{kN}$.m, maximum negative bending moment of the pile body is about $-52.7 \mathrm{kN} . \mathrm{m}$ and the inflection point is $8 \mathrm{~m}$ from the pile top; For main pile at $6.5 \mathrm{~m}$ from the right, maximum positive bending moment is about $35.1 \mathrm{kN} . \mathrm{m}$, maximum negative bending moment is about $-11.1 \mathrm{kN}$.m and the inflection point is $6.5 \mathrm{~m}$ from the pile top.

\subsection{Analysis on Safety Coefficient of Pile Foundation}

Analyze the bending moment distribution of the isolation pile, overpass main pile and ramp pile at both side of the tunnel after the tunnel excavation completed according to the calculation results, as shown in Fig. (9).

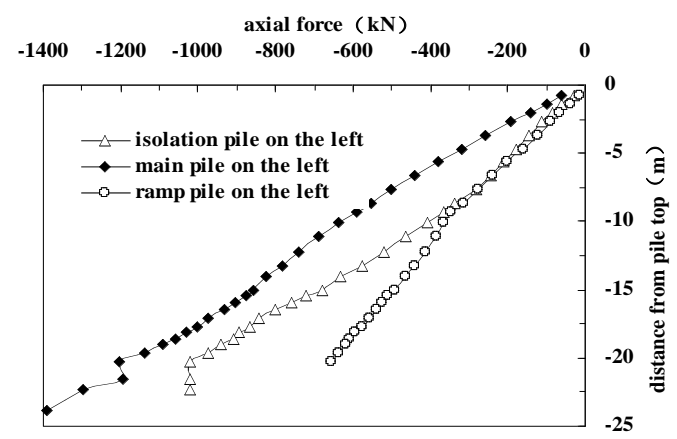

(a) Bending moment distribution of each pile foundation on the left

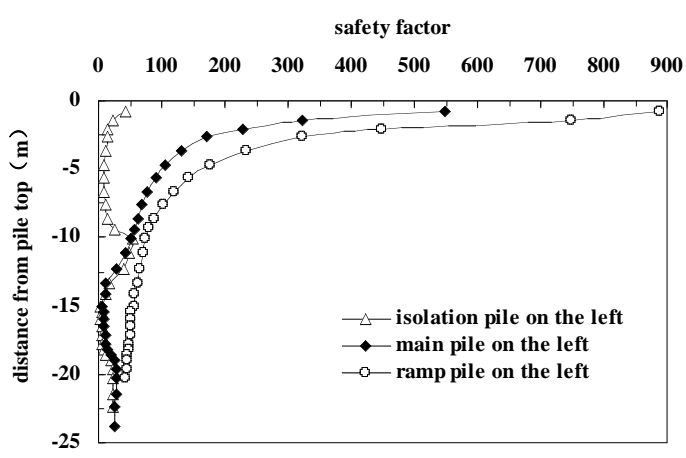

(b) Bending moment distribution of each pile foundation on the right

Fig. (9). Safety factor of piles after excavation completed.

In Fig. (9), we learn that safety coefficient declines in turn for ramp pile, main pile and isolation pile and that the further horizontal distance from the tunnel, the safer. Safety coefficient of each pile tends to declining from top to bottom, the maximum is at the pile top and minimum is at the lower part of the pile body. The minimum safety coefficient of each pile in turn: For isolation pile on the left, minimum safety coefficient is 4.2 at the part $16 \mathrm{~m}$ from the pile top; For main pile on the left, minimum safety coefficient of pile body is 7.34; For ramp pile on the left, minimum safety coefficient of pile body is 43.58; For isolation pile on the right, minimum safety coefficient is 3.5 at the part $15 \mathrm{~m}$ from the pile top.

\section{CONCLUSION}

Using finite difference method, this paper constructed a three dimensional model to simulate the construction process, analyzed ground settlement as well as displacement law and mechanical properties of existing overpass pile foundation in the process of new tunnel construction. Above all, the conclusions are shown as follows:

(1) The settlement range is within $8 \mathrm{~m}$ from both sides of tunnel axis and the closer from tunnel axis, the larger for the settlement. The ground settlement increases with the excavation and maximum of ground settlement $13 \mathrm{~mm}$ occurs after the tunnel construction completed. 
(2) The displacement resulted from the removal of transverse support accounts for $20 \%$ of the total displacement. Pile top settlement in turn: $3.2 \mathrm{~mm}$ for isolation pile on the left; $3.0 \mathrm{~mm}$ for isolation pile on the right; $2.9 \mathrm{~mm}$ for main pile on the left; $3.1 \mathrm{~mm}$ for main pile on the right; $4.4 \mathrm{~mm}$ for ramp pile on the left; $4.7 \mathrm{~mm}$ for main pile at $6.5 \mathrm{~m}$ from the right.

(3) Maximum horizontal displacement of each pile in turn: For isolation pile on the left, right displacement $1.7 \mathrm{~mm}$ of pipe top; For main pile on the left, right displacement 2.1 $\mathrm{mm}$ of the part at $5 \mathrm{~m}$ from pile top; For ramp pile on the left, right displacement $2.4 \mathrm{~mm}$ of the part at $7 \mathrm{~m}$ from pile top; For isolation pile on the right, right displacement 2.3 $\mathrm{mm}$ of middle part of the pile; For main pile on the right, left displacement $1.4 \mathrm{~mm}$ of the part at $6 \mathrm{~m}$ from pile top; For main pile at $6.5 \mathrm{~m}$ from the right, right displacement $1.8 \mathrm{~mm}$ of the part at $1 \mathrm{~m}$ from pile top.

(4) Maximum axial force of each pile in turn: About $1022 \mathrm{kN}$ for isolation pile on the left; About $1388.7 \mathrm{kN}$ for main pile on the left; About $654 \mathrm{kN}$ for ramp pile on the left; About $1368 \mathrm{kN}$ for isolation pile on the right; About 1565.1 $\mathrm{kN}$ for main pile on the right; About $609.3 \mathrm{kN}$ for main pile at $6.5 \mathrm{~m}$ from the right.

(5) Maximum bending moment of each pile in turn: $352.4 \mathrm{kN} . \mathrm{m}$ for isolation pile on the left; $527 \mathrm{kN} . \mathrm{m}$ for main pile on the left; $84.4 \mathrm{kN}$.m for ramp pile on the left; 409.4 $\mathrm{kN}$.m for isolation pile on the right; $603 \mathrm{kN}$.m for main pile on the right; $35.1 \mathrm{kN} . \mathrm{m}$ for main pile at $6.5 \mathrm{~m}$ from the right.

(6) Inflection point of the isolation pile is located $2 / 5$ times the pile length from pile top while inflection point of the main pile is located $1 / 3$ times the pile length from pile top.

(7) Safety coefficients of each pile decline gradually from top to bottom and satisfy the requirement of specification and are even more than the specified safety coefficient 2.0.

Above all, the maximum of ground settlement is $13 \mathrm{~mm}$, the settlement range is within $8 \mathrm{~m}$ from both side of tunnel axis; for isolation pile, the maximum pile top settlement is $3.2 \mathrm{~mm}$, the maximum axial force is $1368 \mathrm{kN}$, the maximum bending moment is $409.4 \mathrm{kN} . \mathrm{m}$, inflection point is located $2 / 5$ times the pile length from pile top and the minimum safety coefficient is 3.5 ; for main pile, the maximum pile top settlement is $4.7 \mathrm{~mm}$ (main pile at $6.5 \mathrm{~m}$ from the right), the maximum axial force is $1565.1 \mathrm{kN}$, the maximum bending moment is $603 \mathrm{kN} . \mathrm{m}$, inflection point is located $1 / 3$ times the pile length from pile top and the minimum safety coefficient is 5.9; for ramp pile, the maximum pile top settlement is 4.4 $\mathrm{mm}$, the maximum axial force is $654 \mathrm{kN}$, the maximum bending moment is $84.4 \mathrm{kN} . \mathrm{m}$ and the minimum safety coefficient is 43.58. Since displacement values of pile foundation are within allowed band and safety coefficients can satisfy the requirement of specification, so the design and construc- tion scheme of this tunnel can ensure the safety of traffic facilities nearby.

\section{CONFLICT OF INTEREST}

The authors confirm that this article content has no conflict of interest.

\section{ACKNOWLEDGEMENTS}

This work is supported by the national natural science foundation of China (No. 51208069; No. 51308082), the applied basic research project of Sichuan Province, China (No. 2014JY0083), the science and technology support program of Sichuan Province, China (2013GZ0147), the science and technology support program of ministry of railways, China (2012G014-D), the eight industrialization project of science and technology of Chengdu City, China (2013JQ-5), and the State Key Laboratory of Geohazard Prevention and Geoenvironment Protection (No. SKLGP2012Z005).

\section{REFERENCES}

[1] B. S. Guan, Main Points of Tunnel Design, Beijing: China Communication Press, 2003

[2] J. D. Morton and K. H. King, "Effects of Tunneling onthe Bearing Capacity and Settlement of Piled Founda-tions", IMM.Proceedings of Tunneling 79, in Lon-don: IMM, pp. 57-68, 1979.

[3] W. M. Sun and Q. S. Wang, "Study on the Influence of Excavation of Tunnel through street on Peripheral pipe groups", Gansu Science and Technology, vol. 22, pp. 165-167, 2006.

[4] X. J. Yang and F. H. Deng, "Study on Effect of Metro tunneling on Carrying capacity of Pile foundation", Chinese Junal of Rock Mechanics and Engineering, vol. 25, pp. 1290-1295, 2006.

[5] F. Liu, T. K. Nian, and Q. Yang, "Research on Influence of Tunneling on Working performance of Adjacent pile foundation", Rock and Soil Mechanics, vol. 28, pp.615-620, 2008.

[6] M. Yang and Q. Sun, "Research Summary of Tunnel Excavation Effects on Adjecent Pile Foundation", Journal of Architecture and Civil Engineering, vol. 28, pp. 118-124, 2011.

[7] C. H. Shi, L. M. Peng, and B. C. Liu, "Influence of Shallow Tunnel Excavation on Ground Surface Buildings", Chinese Junal of Rock Mechanics and Engineering, vol. 23, pp. 3310-3316, 2004.

[8] S. W. Jacobsz, J. R. Standing, R. J. Mair, T. Hagiwara, and T. Sugiyama, "Centrifuge modeling of tunneling near driven piles", Geotechnical Aspect of Underground Construction in Soft Ground, France, pp. 89-94, 2002.

[9] N. Loganathan and H. G. Poulos, "Analytical prediction for tunneling-induced ground movements in clays", Journal of Geotechnical and Geoenvironmental Engineering, ASCE, vol. 124, pp. 846-856, 1998.

[10] K. Takahashi, N. Fukazawa, T. Hagiwara and M. Hosoda, "Observational Control of Slurry Shield Tunnelswith Super Close Spacing Under the Nearby BridgeAbutments Loads", ITA.Proceedings of World Tunnel Congress and 13th ITA Assembly, in Singapore: ITA, pp. 1-6, 2004.

[11] R. J. Mair, R. N. Taylor, and A. Bracegirdle, "Sub surface settle mentprofiles above tunnels in clays", Geotechnique, vol. 43, pp. 315-320, 1993.

[12] Z. L. Liu, "Environmental Kuznets Curve: A New Computational Test and Modeling”, IJACT, vol. 5, no. 5, pp. 551-558, 2013. doi:10.4156/ijact.vol5.issue5.67

[13] R. B. Peck, "Deep excavations and tunneling in soft ground", Proc. 7lnt. Conf. On Soil Mechanics and Foundation Engineering, Mexico City, 1969. 